\title{
Mechanical and Bioactive Properties of Mullite Reinforced Pseudowollastonite Biocomposite
}

(Sifat Mekanik dan Kebioaktifan Biokomposit Pseudowolastonit Diperkuat dengan Mulit)

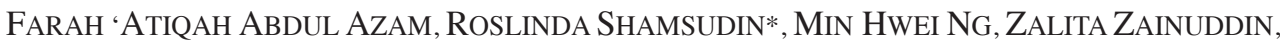 \\ MUHAMMAD AZMI ABDUL HAMID \& RASHITA ABDUL RASHID
}

\begin{abstract}
Bioactive composites consist of pseudowollastonite and mullite synthesized from natural resources was developed for bone implant applications. To realize such applications, a mechanical test of these composites and in vitro bioactivity in SBF solution were studied. The present paper reports pseudowollastonite synthesized from the rice husk ash and limestone reinforced with 10, 20 and $30 \mathrm{wt}$. \% of mullite. Influence of sintering temperature, phase composition, morphology towards mechanical properties of various pseudowollastonite-mullite (PSW-M) composites was examined prior to the bioactivity test. It was found that pseudowollastonite with the addition of $20 \mathrm{wt} . \%$ of mullite sintered at $1150^{\circ} \mathrm{C}$ gave the best result for diametral tensile strength (DTS) and hardness with the value of $8.8 \pm 0.15 \mathrm{MPa}$ and $3.79 \pm 0.13 \mathrm{GPa}$, respectively. The obvious increment in the mechanical strength was due to the formation of liquid phase $\mathrm{CaAl}_{2} \mathrm{O}_{3}$ during sintering at $1150^{\circ} \mathrm{C}$. In addition, the formation of fibrous apatite (HA) layer of amorphous calcium phosphate (ACP) with Ca/P ratio 1.8 on PSW20M sample confirmed the good bioactivity of the composite.
\end{abstract}

Keywords: Bioactivity; mechanical; mullite; pseudowollastonite

ABSTRAK

Komposit bioaktif yang terdiri daripada pseudowolastonit dan mulit disintesis daripada sumber semula jadi telah dibangunkan untuk aplikasi implan tulang. Untuk merealisasikan aplikasi ini, ujian mekanik dan kebioaktifan secara in vitro dalam larutan badan tersimulasi (SBF) bagi komposit ini telah dijalankan. Kajian pada kali ini melaporkan pseudowolastonit yang disintesis daripada abu sekam padi dan batu kapur yang diperkuat dengan 10, 20 dan 30 $\%$ bt. kandungan mulit. Pengaruh suhu sinteran, komposisi, fasa dan morfologi terhadap sifat mekanik komposit pseudowolastonit-mulit (PSW-M) telah dianalisis sebelum ujian kebioaktifan dijalankan. Keputusan mendapati pseudowolastonit dengan penambahan $20 \%$ bt. mulit yang disinter pada suhu $1150^{\circ} \mathrm{C}$ memberikan hasil yang terbaik untuk kekuatan regangan diameter (DTS) dan kekerasan masing-masing dengan nilai $8.8 \pm 0.15$ MPa dan $3.79 \pm$ $0.13 \mathrm{GPa}$. Peningkatan kekuatan mekanik yang ketara ini adalah disebabkan oleh pembentukan fasa cair $\mathrm{CaAl}_{2} \mathrm{O}_{3}$ semasa proses sinteran pada suhu $1150^{\circ} \mathrm{C}$. Di samping itu, pembentukan lapisan apatit (HA) jenis kalsium fosfat amorfus (ACP) dengan nisbah (Ca / P: 1.8) bagi sampel PSW20M pada hari ke-7 membuktikan kebioaktifan yang baik daripada komposit ini.

Kata kunci: Kebioaktifan; mekanik; mulit; pseudowolastonit

\section{INTRODUCTION}

The development of bioactive ceramics has moved toward having a bioceramic material that can form a direct bond with bone and tissue as well as providing good mechanical properties (Best et al. 2008). Over the past few years, calcium silicates have been considered for low-load bearing and hard tissue replacement in biomedical application. Calcium silicate $\left(\mathrm{CaSiO}_{3}\right)$ or wollastonite has received much attention due to its high biocompatibility and bioactivity in the human body (Anjaneyulu \& Sasikumar 2014; De Aza et al. 2006; De La Casa-Lillo et al. 2011). Calcium silicate could be synthesized using synthetic and natural sources as a precursor. Some of them were used as a filler in bone implants (Engqvist et al. 2006), a coating on inert implants such as titanium alloy (Cannillo et al. 2009; Liu \& Ding 2002) or used as a bulk. However, because of many constraints and problems aroused from the coating of implants after a certain time period, the performance of bioceramics is better to be improved as a bulk.

Recent work has focused on biocomposite materials because of their associated bioactivity properties and good mechanical performances. Researchers have struggled to develop material with good biocompatibility and superior mechanical properties. Several attempts to develop biocomposite using numerous types of reinforcement including foreign oxides and metallic dispersions were reported in the literature. Several studies have reported that the integration of $\mathrm{Ti}$ into $\mathrm{CaSiO}_{3}$ sintered at high sintering 
temperature reduced the dissolution rate. Numerous researchers have explored the role and interaction of bioinert ceramic reinforcement towards hydroxyapatite (HAp) and calcium phosphate (CaP). Hardness and fracture toughness of $\mathrm{HAp}-\mathrm{ZrO}_{2}$ and $\mathrm{HAp}-\mathrm{Al}_{2} \mathrm{O}_{3}$ were much improved as compared to the HAp itself after the addition of zirconia $\left(\mathrm{ZrO}_{2}\right)$ and alumina $\left(\mathrm{Al}_{2} \mathrm{O}_{3}\right)$ (Kim et al. 2003; Silva et al. 2001; Zhang et al. 2006). For the bioceramics material, the brittleness possess a challenge. Therefore, it is combined with other materials to obtain good physical properties for load-bearing implant applications.

As far as the authors are aware, very little work has been carried out on the ceramic reinforcement like alumina with calcium silicate. A study has reported that, after sintering process, $\mathrm{CaSiO} / \mathrm{Al}_{2} \mathrm{O}_{3}$ composite formed an alumina-rich calcium aluminates whereby a better hardness and toughness of the composite was attained (Shirazi et al. 2014). Recently, the application of calcium silicate and mullite as ceramic reinforcement for the biomedical application also has been highlighted by several researchers. The mullite addition into HAp favored the decomposition of HA into $\alpha / \beta$ TCP and supported the osteoconduction after 12-week implantation in vivo, thus became an appropriate composite for bone cell adhesion and proliferation (Nath et al. 2011). Based on the reviewed by Park and Bronzino (2002), mullite could be categorized as bioinert material and has been successfully made as a synthetic cellular solid in the form of foamed mullite which mimics the cancellous bone.

Mullite is one of the ceramic materials which are stable at the atmospheric pressure but rarely found as a mineral in nature. It is the refractory material that generally used for high-temperature applications which constitutes the alumina and silica phase. Mullite is a solid solution compound with stoichiometries of either silicarich $3 \mathrm{Al}_{2} \mathrm{O}_{3} .2 \mathrm{SiO}_{2}\left(3: 2\right.$ mullite) or alumina-rich $2 \mathrm{Al}_{2} \mathrm{O}_{3}$. $\mathrm{SiO}_{2}\left(2: 1\right.$ mullite). Mullite has a density $\left(3.2 \mathrm{~g} / \mathrm{cm}^{3}\right)$ much lower than zirconia $\left(5.6 \mathrm{~g} / \mathrm{cm}^{3}\right)$ and alumina $\left(3.96 \mathrm{~g} / \mathrm{cm}^{3}\right)$, hardness $(15 \mathrm{GPa})$ greater than $\mathrm{ZrO}_{2}(12 \mathrm{GPa})$, and an adequate fracture toughness (2.5 MPam0.5) (Schneider et al. 2008). The physical and mechanical properties of the calcium phosphate-mullite composite were enhanced significantly after mullite additions (Nath et al. 2012). Therefore, calcium silicate-mullite biocomposite can be developed using mullite as dispersions to produce a lightweight material with good mechanical and bioactive properties. Consequently, in this study, the effects of mullite addition on the mechanical properties and the bioactivity of the pseudowollastonite-mullite (PSW-M) biocomposites were studied.

\section{MATERIALS AND METHODS}

\section{SYNTHESIS OF MATERIAL}

The synthesis process of calcium silicate was conducted using the solid-state method. Limestone $\left(\mathrm{CaCO}_{3}\right)$ and rice husk ash $\left(\mathrm{SiO}_{2}, 98 \%\right)$ were used as a precursor for $\mathrm{CaO}$ and $\mathrm{SiO}_{2}$, respectively. Calcium oxide $(\mathrm{CaO})$ was obtained from the calcination of limestone and silicon dioxide $\left(\mathrm{SiO}_{2}\right)$ from the burned rice husk ash with the ratio of 55:45 as described in the previous study by Hamisah et al. (2013). The $\mathrm{CaO}-\mathrm{SiO}_{2}$ mixture was dried and sintered at the temperature of $1250^{\circ} \mathrm{C}$ for $1 \mathrm{~h}$ at $5^{\circ} \mathrm{C} / \mathrm{min}$ which then transformed the mixture into pseudowollastonite $\left(\alpha-\mathrm{CaSiO}_{3}\right)$ phases. XRD of calcined calcium silicates at $1250^{\circ} \mathrm{C}$ showed the pure pseudowollastonite peak. Another raw material, andalusite powder from Terengganu, Malaysia, was sintered at $1450^{\circ} \mathrm{C}$ for $4 \mathrm{~h}$ at $5^{\circ} \mathrm{C} / \mathrm{min}$ using the HighTemperature Naberterm Furnace to produce a pure mullite phase. This mullite acts as the reinforcement in the pseudowollastonite matrix. The starting material pseudowollastonite and mullite have an average particle size of 26.5 and $11.11 \mu \mathrm{m}$, respectively. Table 1 shows some of the physical properties of pseudowollastonite and mullite used in this experiment.

TABLE 1. Physical properties of pseudowollastonite and mullite

\begin{tabular}{lcc}
\hline Properties & Pseudowollastonite & Mullite \\
\hline Colour & White & brownish \\
Average size $(\mu \mathrm{m})$ & 26.7 & 11.11 \\
Melting Point $\left({ }^{\circ} \mathrm{C}\right)$ & $\geq 1300$ & $\geq 1700$ \\
Density $\mathrm{g} / \mathrm{cm}^{3}$ & 2.98 & 3.17 \\
\hline
\end{tabular}

In the present experiments, pseudowollastonite powder is ball milled with mullite at different compositions using a rotational speed of $500 \mathrm{rpm}$ for $15 \mathrm{~min}$ in acetone to break the agglomerates and have a homogenous, as well as fine structure. The amount of mullite in the composite is varied by $(10,20$ and 30 wt. \%) as stated in Table 2. Pseudowollastonite and pseudowollastonite-mullite composite powder were moulded into the stainless steel mould under a pressure of $2.5 \mathrm{~T}$ to form a pellet with size $\pm 13 \mathrm{~mm}$ diameters. Both pure pseudowollastonite and biocomposite pellet were sintered at low temperature $800^{\circ} \mathrm{C}, 1000^{\circ} \mathrm{C}$ and the highest temperature is $1150^{\circ} \mathrm{C}$. Different sintering temperatures were used in pellet sintering and changes in mechanical properties with respect to sintering temperature was observed. The maximum sintering temperature used was $1150^{\circ} \mathrm{C}$ because the pseudowollastonite-mullite composites pellet will melt and deformed at $1200^{\circ} \mathrm{C}$. After that, the density of the compact was measured by the Archimedes' method using water as the fluid. The samples were weighed in air and water, and the density was measured using the equation:

$$
\rho=\frac{m \text { water }}{m \text { air }-m \text { water }}(\rho \text { water }=\rho \text { air })+\rho \text { air }
$$

where $\rho$ is the density of the material; $m$ water is the weight in grams $(\mathrm{g})$ of the specimen in water; $\mathrm{m}$ air is the weight in grams $(\mathrm{g})$ of the specimen in air; and $\rho$ water is the density of water. The relative density was then calculated by 
TABLE 2. Sample designation for different composition of PSW-mullite composite

\begin{tabular}{cccc}
\hline \multirow{2}{*}{ Sample designation } & \multicolumn{2}{c}{ Composition (\%) } & Sintering condition \\
\cline { 2 - 3 } & Pseudowollastonite & Mullite & \\
\hline PSW & 100 & 0 & $800^{\circ} \mathrm{C}, 1000^{\circ} \mathrm{C}, 1150^{\circ} \mathrm{C} \mathrm{for} 2 \mathrm{~h}$ \\
PSW10M & 90 & 10 & $800^{\circ} \mathrm{C}, 1000^{\circ} \mathrm{C}, 1150^{\circ} \mathrm{C}$ for $2 \mathrm{~h}$ \\
PSW20M & 80 & 20 & $800^{\circ} \mathrm{C}, 1000^{\circ} \mathrm{C}, 1150^{\circ} \mathrm{C}$ for $2 \mathrm{~h}$ \\
PSW30M & 70 & 30 & $800^{\circ} \mathrm{C}, 1000^{\circ} \mathrm{C}, 1150^{\circ} \mathrm{C}$ for $2 \mathrm{~h}$ \\
\hline
\end{tabular}

comparing the measured data and the theoretical densities $\left(\mathrm{CaSiO}_{3}=2.905 \mathrm{~g} / \mathrm{cm}^{3}\right.$, Mullite $\left.=3.2 \mathrm{~g} / \mathrm{cm}^{3}\right)$.

\section{CHARACTERIZATION OF SINTERED BIOCOMPOSITE}

The element composition of the synthesized pseudowollastonite and mullite was examined using X-Ray Fluorescence (XRF). Phase compositions of prepared samples were identified by X-ray diffraction (XRD) (BRUKER, D8 ADVANCE) (Karlsruhe, Germany) with a CuKa radiation $(\mathrm{k}=0.154 \mathrm{~nm})$ and a Ni filter, at a working voltage of $40 \mathrm{kV}$ and a working current of $30 \mathrm{~mA}$.

Microstructural characterizations were carried out using field emission scanning electron microscope (FESEM) (Merlin) accompanied with the energy dispersive spectroscopy (EDAX).

\section{MECHANICAL ASSESSMENT OF THE PSW/MULLITE BIOCOMPOSITE}

There are many mechanical tests to measure the tensile strength of specimen especially bioceramics. For instance, four-point bending test, flexural test and diametral compression test (DCT). In diametral compression test, the result of tensile strength for a brittle material is more consistent as compared to the common method such as the four-point bending test (Hsu et al. 2007; Osendi \& Baudı 'n 1983). This is because, in DCT method, the bulk material is exposed to the tensile stresses. Whereas in four-point bending test, only the maximum tensile stresse is subjected on the surface of the specimen. Thus, the strength values may be greatly affected by the surface imperfection if any (Marghussian \& Sheikh-Mehdi Mesgar 2000). According to Bieniawski and Hawkes (1978), the value obtained from the DCT method is much lower than that from the flexural test, but higher than that from the direct tensile test. Thus, lower strength values in DCT test is anticipated. According to Harabi and Chehlatt (2013), the relationship between measured tensile strength $\left(\sigma_{t}\right)$ value and its equivalent flexural (bending) strength $\left(\sigma_{f}\right)$ is given in (1);

$$
\sigma_{\mathrm{f}}(\mathrm{MPa})=2.7 \sigma_{\mathrm{t}}(\mathrm{MPa})
$$

In this experiment, the tensile strength of the material is examined using diametral compression test (DCT). The reliability and efficiency of this method for the fracture test of bioceramics have been confirmed by Elghazel et al. (2015) using a standard method for disc shape concrete or ceramics ASTM C 496/C 496M - 04 (2011). INSTRON 8874 with the load cell $5 \mathrm{kN}$ and loading speed of $0.075 \mathrm{~mm} /$ min is used. In diametral compression test, a disc sample is used to determine the tensile strength by subjecting the specimen to two opposite sides of the normal load. The applied load develops across the diametrical plane of the disc parallel to the loading direction. Figure 1 illustrates the diametral compression test. Fracture occurs along the vertical plane that passes through the center of the disc. Here, the tensile stress is directly proportional to the compressive load applied. Such diametral tensile strength is calculated using (2).

$$
\sigma_{\mathrm{t}}=\frac{2 P}{\pi D T}
$$

where $\sigma_{t}$ is the maximum tensile strength (MPa); $\mathrm{P}$ is the maximum applied load at fracture (Newton); D is the diameter of the samples measured from the center $(\mathrm{mm})$; and $\mathrm{T}$ is the thickness $(\mathrm{mm})$ of the disc. To calculate the stress using (2), the fracture must be initiated at the center of the disc across the disc. In order to assure the validity of the test, the contact width of the sample must be less than $20 \%$ of the sample diameter and a near-vertical fracture occurred (Pilliar et al. 2001). The crushing of the disc sample at the loading points that occasionally happen in brittle ceramic materials will cause invalid test results.

Microhardness testing machine was used to measure the Vickers hardness values of the samples. In Vickers indentation technique, well-polished specimens were subjected to the Vickers indenter: $10 \mathrm{~kg}$ load at $15 \mathrm{~s}$ was applied onto the specimen surface by diamond pyramid tip. For each composition, four to five specimens were tested for diametral tensile strength and microhardness and the results were then averaged.

\section{BIOACTIVITY TEST IN SIMULATED BODY FLUID}

The in vitro bioactivity of the PSW/Mullite composite was studied by soaking all samples in the SBF solution prepared by the method proposed by Kokubo and Takadama (2006). The samples were soaked in the polyethelyne PE holder and keep in the incubator at $36.7^{\circ} \mathrm{C}$ for $1,3,7$ and 14 days. The SBF solution was changed every 3 days to maintain the ion in the solution. After soaking in the SBF solution for every respective day, the sample was taken out and immersed in acetone for $2 \mathrm{~h}$ to stop the reaction, rinsed with distilled water and left dried in the incubator for $24 \mathrm{~h}$. The in vitro bioactivity assessment is the prior test before proceeding to the in vivo evaluations. 


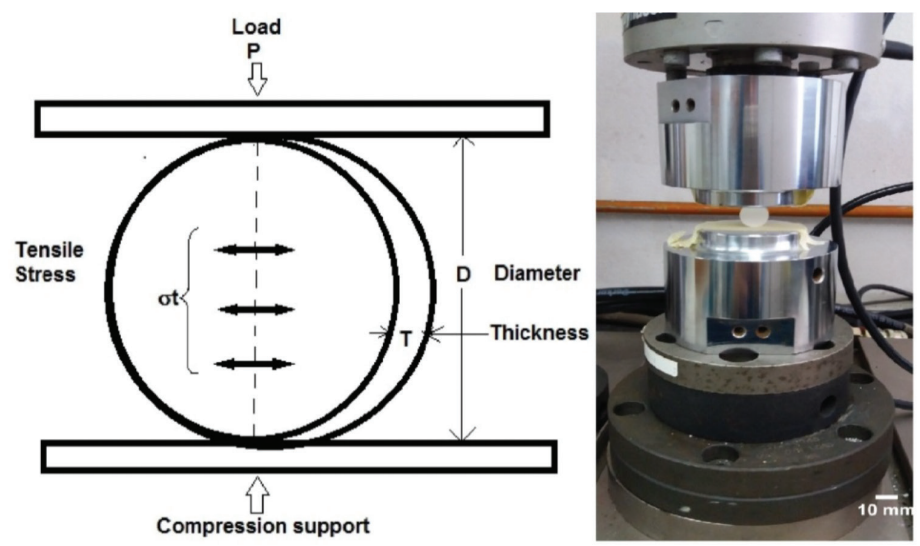

FIGURE 1 . The illustration of diametral compression test measured using INSTRON 8874 with the load cell $5 \mathrm{kN}$

\section{RESULTS AND DISCUSSION}

\section{PHASE COMPOSITION AND DENSITY}

The XRD results showed the spectra of pseudowollastonitemullite composite for different compositions sintered at different temperatures. Figure 2 shows that the peak intensity of mullite increases as the content of mullite in the composite increased. A very intense and sharp peak could be seen at every sintering temperature. Based on the XRD spectra in Figure 2, the increasing temperature from $800^{\circ} \mathrm{C}-1000^{\circ} \mathrm{C}$ caused no significant changes of phases for different amount of mullite additions at 10-30 wt. \%. Furthermore, it could be seen obviously that, the new phase of calcium aluminium oxide existed for different mullite concentration at $1150^{\circ} \mathrm{C}$ sintering temperature. Shirazi et al. (2014) reported that the formation of new phase $\mathrm{CaAl}_{2} \mathrm{O}_{4}$ (ref. no.JCPDS 001-0888) at peak angles of 30, 35.5 and 37.2 (Figure 2(g)- 2(i)) is due to the reaction between alumina and calcium silicate. The formation of calcium aluminum oxide at the temperature of $1150^{\circ} \mathrm{C}$ is based on the following reaction.

$$
\mathrm{CaSiO}_{3}+\mathrm{Al}_{2} \mathrm{O}_{3} \longrightarrow \mathrm{CaAl}_{2} \mathrm{O}_{4}+\mathrm{SiO}_{2}
$$

In addition, the presence of gehlenite phase could also be observed at peak angles of 31.4,53.1 and 29.1 The formation of softer sintered phase gehlenite is a common for pressureless sintering of mullite (Nath et al. 2008). The relationship between calcium aluminum oxide and gehlenite formation with mechanical properties of the material will be further discussed in the next section.

In general, the sintering temperature is the crucial factor that affects the densification of the composite. The density profile of the sintered component in Figure 3 shows that densification assisted by sintering. Based on the graph, the density for all samples were significantly increases as we increase the sintering temperature from $800^{\circ} \mathrm{C}$ to $1150^{\circ} \mathrm{C}$. A drastic change of density could be observed on PSW samples when the temperature increased

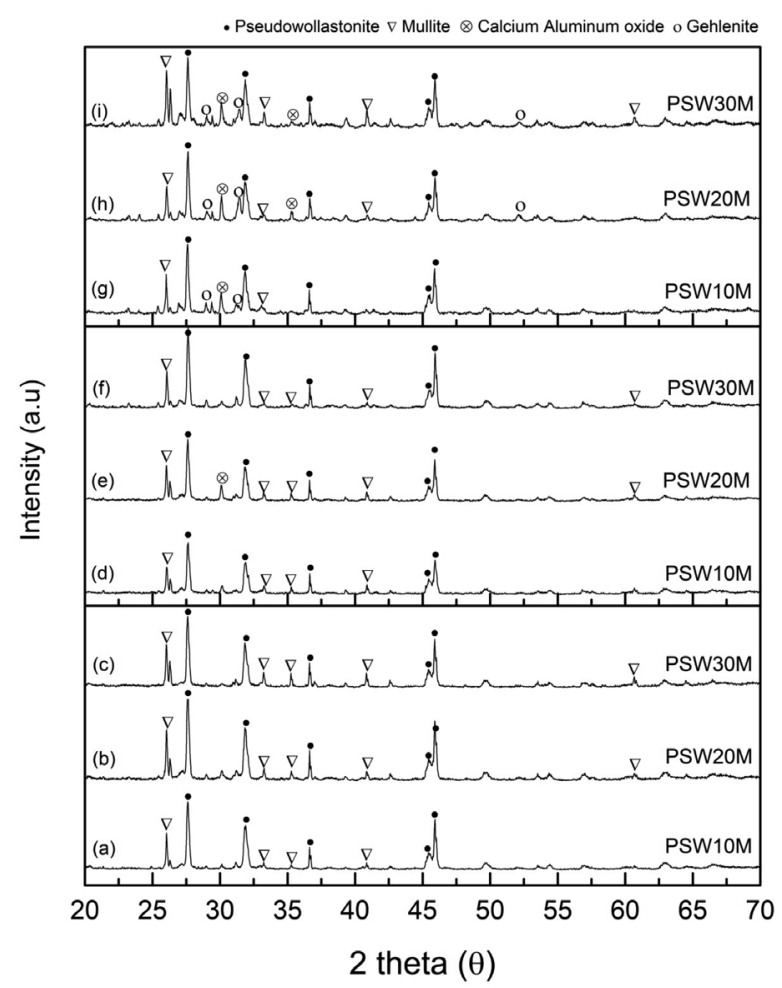

FIGURE 2. XRD patterns of the composite discs with different compositions i.e. PSW10M, PSW20M, PSW30M after sintering at $800^{\circ} \mathrm{C}(\mathrm{a}, \mathrm{b}, \mathrm{c}), 1000^{\circ} \mathrm{C}(\mathrm{d}, \mathrm{e}, \mathrm{f})$ and $1150^{\circ} \mathrm{C}(\mathrm{g}, \mathrm{h}, \mathrm{i})$ for $2 \mathrm{~h}$

from $800^{\circ} \mathrm{C}$ to $1000^{\circ} \mathrm{C}$. Whereas for PSW $20 \mathrm{M}$ composite, the density was sharply improved at the range between $1000^{\circ} \mathrm{C}$ and $1150^{\circ} \mathrm{C}$. The highest relative density of $2.895 \mathrm{~g} / \mathrm{cm}^{3}$ shows in Figure 3 is pseudowollastonite with 20 wt. $\%$ mullite addition. At the same sintering temperature with greater amount of mullite (30 wt. \%) additions, the density is decrease $\left(2.72 \mathrm{~g} / \mathrm{cm}^{3}\right)$. Further additions of mullite seems like do not assist a better densification which might due to unnecessary amount of mullite additions that will cause excessive large grain of mullite-mullite contact in the sintered body thus, pore elimination occur less efficiently (Nath et al. 2008). 


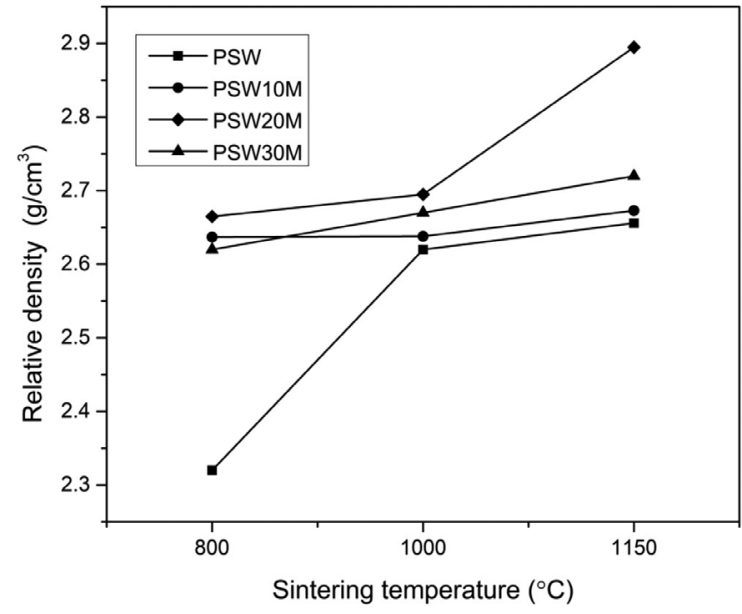

FIGURE 3 . Relative density vs porosity of the samples with different firing temperatures

\section{EFFECT OF MULLITE ADDITIONS AND SINTERING TEMPERATURE ON MECHANICAL PROPERTIES}

Figure 4 shows the relationships between the diametral tensile strength (DTS) and the sintering temperature corresponded to different pseudowollastonite-mullite compositions. The DTS increased along with the sintering temperature. The highest strength of $100 \% \mathrm{PSW}$ sample without any reinforcement is $5.04 \pm 0.20 \mathrm{MPa}$. Additions of $20 \mathrm{wt}$ \% mullite reinforcement increased the strength to $8.8 \pm 0.15 \mathrm{MPa}$ at the sintering temperature of $1150^{\circ} \mathrm{C}$. For the reason that, most of the micro pores are eliminated at $1150^{\circ} \mathrm{C}$ (Figure 5). However, further increased of mullite content to $30 \mathrm{wt}$. \% reduced the strength to $6.32 \pm 0.15$. Shirazi et al. (2014) remark that the presence of alumina particle at $15 \mathrm{wt} . \%$ concentration in calcium silicate matrix enhances the hardness and fracture toughness of calcium silicate. However, at 25 wt. \% alumina concentration, the mechanical properties of $\mathrm{CaSiO}_{3}-\mathrm{Al}_{2} \mathrm{O}_{3}$ decrease. The decrease in the mechanical strength at higher alumina content is attributing to the incomplete reaction between calcium silicate and alumina at low sintering temperature. Therefore, increasing mullite content in this study over 20 wt. \% also decreases the DTS value in reason. Nevertheless, the DTS value of sintered pseudowollastonite $\left(\alpha-\mathrm{CaSiO}_{3}\right)$ after mullite additions in this study is much improved than that of synthesized $\mathrm{CaO}-\mathrm{SiO}_{2}$ cements with few other methods such as sol gel techniques that have diametral strength about 2.2-2.4 $\mathrm{MPa}$ when sintered at $1000^{\circ} \mathrm{C}$ (Chen et al. 2015) and hydrothermal method for 2.9 MPa (Ding et al. 2009), respectively.

One of the factors that have significant effects on the mechanical properties of material is the liquid phase sintering (LPS) mechanism that happened during sintering. During LPS reaction, the atoms become more mobilized and re-arranged. In addition, the grain growth was promoted through the movement of particle among larger granule (Maitra et al. 2006). The formation of new phase $\mathrm{CaAl}_{2} \mathrm{O}_{3}$ occurred at temperature $1150^{\circ} \mathrm{C}$ (Figure 2). Such liquid phase enhances the densification thus becomes the important reason in improving the mechanical properties. Several researches also highlighted that the existence of calcium aluminium oxide $\mathrm{CaAl}_{2} \mathrm{O}_{4}$ (Figure 2) will act as the hardener phase that enhances the strength of the HA composite (Gautier et al. 1997; Horng \& Min 1994; Ji \& Marquis 1992). In addition, Nath et al. (2010) also point out the benefit of using mullite particle as reinforcement because of good densification that could be achieved due to the liquid-phase sintering. The study on ternary phase diagram $\mathrm{CaO}-\mathrm{Al}_{2} \mathrm{O}_{3}-\mathrm{SiO}_{2}$ system prove the formation of gehlenite, anorthite and calcium aluminum oxide $\left(\mathrm{CaAl}_{2} \mathrm{O}_{3}\right)$ for calcium silicate containing mullite composite which is dependable on the sintering temperature (Zhao et al. 2007).

The same trend is perceived for hardness test (Figure 4). As would be expected, the hardness increased as the temperature increases from $800^{\circ} \mathrm{C}-1150^{\circ} \mathrm{C}$. The vickers hardness value of about $2.31 \pm 0.14 \mathrm{GPa}$ is obtained for pseudowollastonite pellet when sintered at $1150^{\circ} \mathrm{C}$. Consequently, the best hardness value was $3.79 \pm 0.14 \mathrm{GPa}$ given by PSW20M sample when sintered at this highest temperature. This result is comparable to other work that attained the micro hardness value of $2.6 \mathrm{GPa}$ for synthesized pseudowollastonite sintered at $1150^{\circ} \mathrm{C}$ from local raw material $\mathrm{CaCO}_{3}$ which then improved up to $3.1 \mathrm{GPa}$ with the addition of 5 wt. $\%$ of $\mathrm{B}_{2} \mathrm{O}_{3}$ (Harabi \& Chehlatt 2013). Other research also reported that $\mathrm{HA}(20 \mathrm{wt}$. \%)- wollastonite (80 wt. \%) composite sintered at $1000^{\circ} \mathrm{C}$ for $2 \mathrm{~h}$ reached the hardness of $3.92 \mathrm{GPa}$. Back to this study, as the mullite content increased to $30 \mathrm{wt}$. \%, both of DTS and hardness decreased. Such results are in line with the earlier results

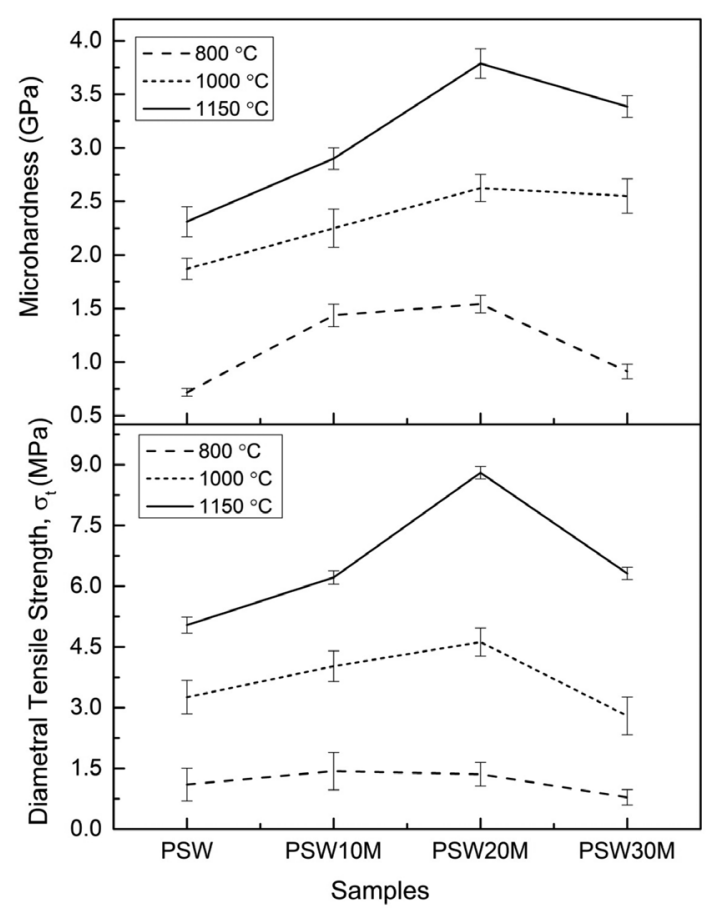

FIGURE 4. Microhardness and diametral tensile strength of sintered pseudowollastonite-mullite (PSW-M) composite plotted against different compositions 
reported in literature (Nath et al. 2012) which the highest strength of HAp achieved with not more than $20 \mathrm{wt}$. \% addition of mullite. Thus, it can be possibly deduced that, 20 wt. $\%$ of mullite reinforcement caused the optimum amount of $\mathrm{CaSiO}_{3}$-mullite contact which leads to the far-reaching sintering reaction.

The mechanical properties of the materials are also interrelated with the microstructural features. The FESEM micrograph in Figure 5 shows the surface microstructure of pseudowollastonite-20\% mullite disc sintered at different sintering temperatures with distinct and interconnected pores. High porosities reduced the fracture toughness and strength of the materials. More abundant pores could be seen for the PSW20M composite sintered at $800^{\circ} \mathrm{C}$ compared to the higher sintering temperature at $1150^{\circ} \mathrm{C}$ (Figure 5) which supports our results that high DTS is attained for samples sintered at higher temperature. A much improved compactness could be seen for PSW20M sample sintered at $1150^{\circ} \mathrm{C}$ as compared to the pseudowollastonite (Figure 5(c) $\& 5(d))$. Eventually, during sintering at $1150^{\circ} \mathrm{C}$, the particles are distorted hence abruptly eliminates the micro pores at the grain boundaries. Other samples with different weight percentage of mullite have insignificant differences in terms of morphology with this pseudowollastonite- $20 \%$ mullite composite. This condition happened because the presence of liquid phase during sintering at high temperature enhanced the mullite grain growth hence assists the pore closure as reported by Bakr (2012). As a result of capillary action during liquid phase sintering (LPS), liquid flow leads to particle rearrangement. This caused larger voids and micro pores reduced and contribute to densification. The particle rearrangement, diffusion of mass into pores and grain growth are some of the phenomenon that normally occurred during sintering.
The mullite reinforced composites up to $20 \mathrm{wt}$. \% shows the greatest diametral tensile strength $(8.8 \pm 0.15$ $\mathrm{MPa})$ and hardness $(3.79 \pm 0.13 \mathrm{GPa})$ compared to the nonreinforced wollastonite $(5.04 \pm 0.20 \mathrm{MPa})$ and $(2.31 \pm 0.14$ $\mathrm{GPa})$, respectively. Ultimately, based on the comparisons of different mullite compositions and sintering temperatures, it can be concluded that the best mechanical strength which includes DTS and hardness is given by PSW20M sintered at $1150^{\circ} \mathrm{C}$ that has the lowest porosity and a good densification. Therefore, the following study of the in vitro bioactivity in SBF solutions has focused on the investigation of the PSW20M sample.

\section{APATITE FORMATION ON PSW20M COMPOSITES}

The formation of the apatite phase on the surface of the material was monitored during the in vitro test in SBF solution. According to Kokubo and Takadama (2006), the ability of the implanted biomaterial to form interfacial bonds with tissues and bone in vivo could be predicted by the examination of apatite formation on material in the SBF solution. Figure 6 shows the PSW20M sample before immersion and after immersion up to 14 days of immersion in the SBF solution. The decreased in intensity of the sharp peaks of pseudowollastonite and mullite could be clearly observed from day 0 to day 14 . This shows that the dissolution has occurred. At day 7 , the presence of a broad peak at $2 \theta=32-34^{\circ}$ indicates the formation of amorphous HA started to form. This amorphous peak remains and increases its intensity until day 14 . During the immersion of PSW20M samples in the SBF solution, the ion exchange from the material surface $\mathrm{Ca}^{2+}$ into the solution and $\mathrm{H}^{+}$ion from the SBF solution occurred. The negatively charged surface with the functional group ( $\mathrm{Si}-\mathrm{O})$
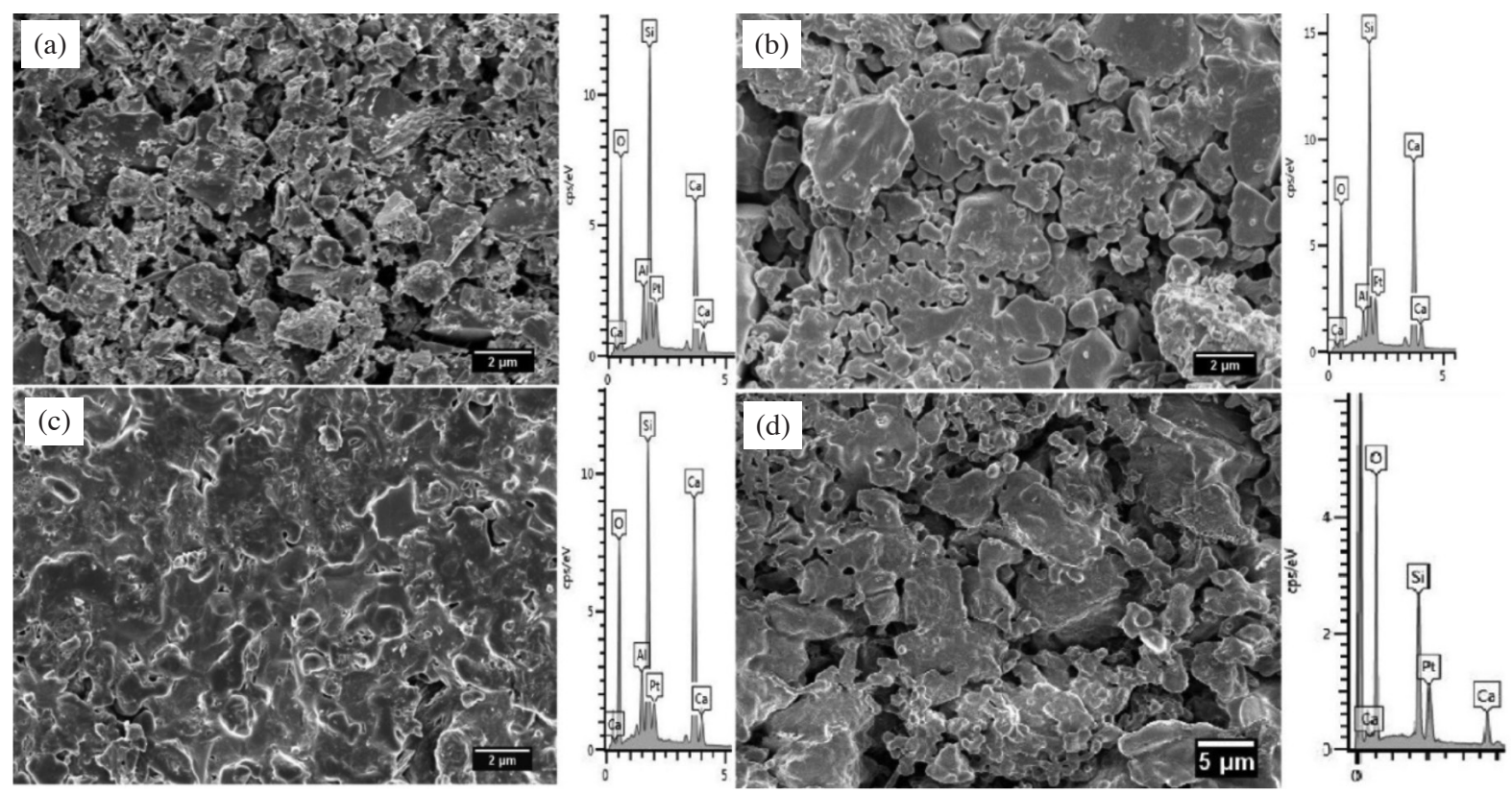

FIGURE 5. The morphology of PSW $/ 20 \% \mathrm{M}$ disc surface shows the disc composite at $5000 \times$ magnification (in lens mode) sintered at (a) $800^{\circ} \mathrm{C}$, (b) $1000^{\circ} \mathrm{C}$ and (c) $1150^{\circ} \mathrm{C}$ and pseudowollastonite disc sintered at $1150^{\circ} \mathrm{C}$ 


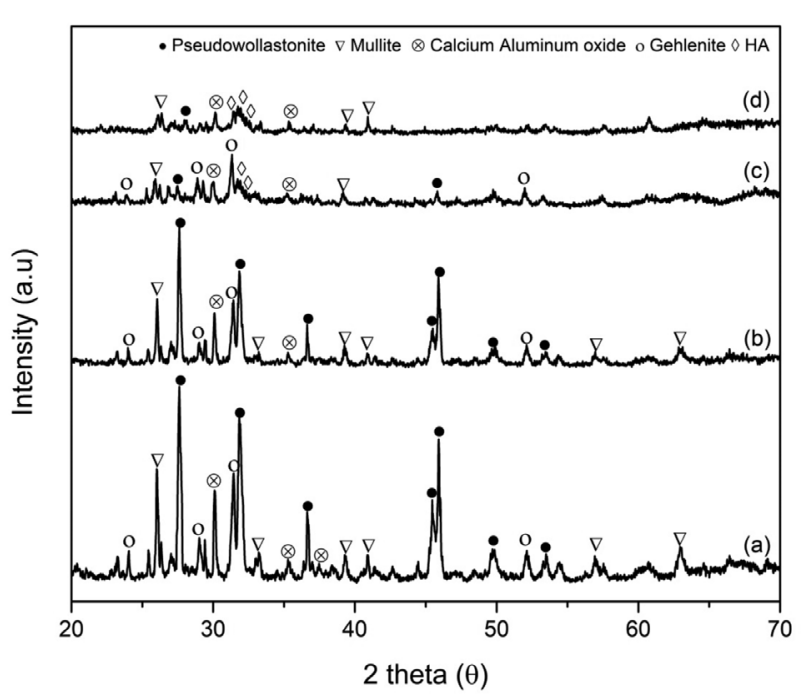

FIGURE 6. XRD patterns of the PSW20M samples sintered at $1150^{\circ} \mathrm{C}$ soaking in SBF solutions for (a) 0, (b) 3, (c) 7, and 14 days

is then formed on the sample surface. This Si-O- induces apatite nucleation (Hamisah et al. 2016). Based on the FTIR spectrum in Figure 7, the bending band for the silicon ion (Si-O-) could be observed at the wavenumber 1067.18 $\mathrm{cm}^{-1}$. In addition, after 7 days, the presence of PO groups could be observed at the wavenumber $1020 \mathrm{~cm}^{-1}$ which demonstrates the apatite formation.

FESEM images of PSW20M samples before and after immersion in SBF solutions for 0, 7 and 14 days are displayed in Figure 8. The rough and fibrous layers deposited after 7 days of immersion is the apatite layer that formed on the samples. These results are confirmed by EDS analysis which shows the presence of $\mathrm{Ca} / \mathrm{P}$ ratio is 1.8 after 7 days of immersion in SBF solution. This ratio indicates the formation of amorphous calcium phosphate (ACP). Dorozhkin (2007) highlighted that range of ACP must be in the range of 1.2 to 2.2 . Thus, it may be concluded that pseudowollastonite-mullite composite exhibit good bioactivity properties.

\section{CONCLUSION}

Pseudowollastonite containing mullite was successfully prepared and sintered at various temperatures. The role of mullite as reinforcement was proven capable of enhancing the mechanical properties of the pseudowollastonite. The liquid phase sintering reaction which occurred at $1150^{\circ} \mathrm{C}$ promotes grain growth thus assisted densification. The optimum amount of mullite addition to pseudowollastonite at 20 wt. \% gave the best hardness and diametral tensile strength. The strength of composite will be deteriorated as the amount of mullite increased. The presence of HA peak from XRD and the apatite morphology from FESEM after immersion in SBF solutions for 7 days showed that PSW20M composite was bioactive. Therefore, this finding suggested that pseudowollastonite-mullite composite synthesized

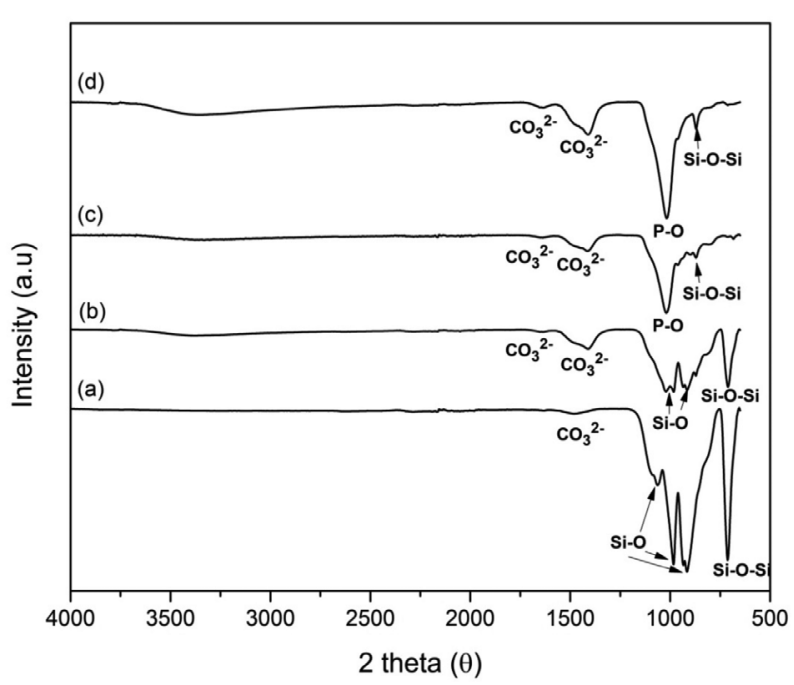

FIGURE 7. FTIR spectra of the PSW20M samples sintered at

$1150^{\circ} \mathrm{C}$ and soaked in SBF solutions for (a) 0 , (b) 3,

(c) 7 and (d) 14 days
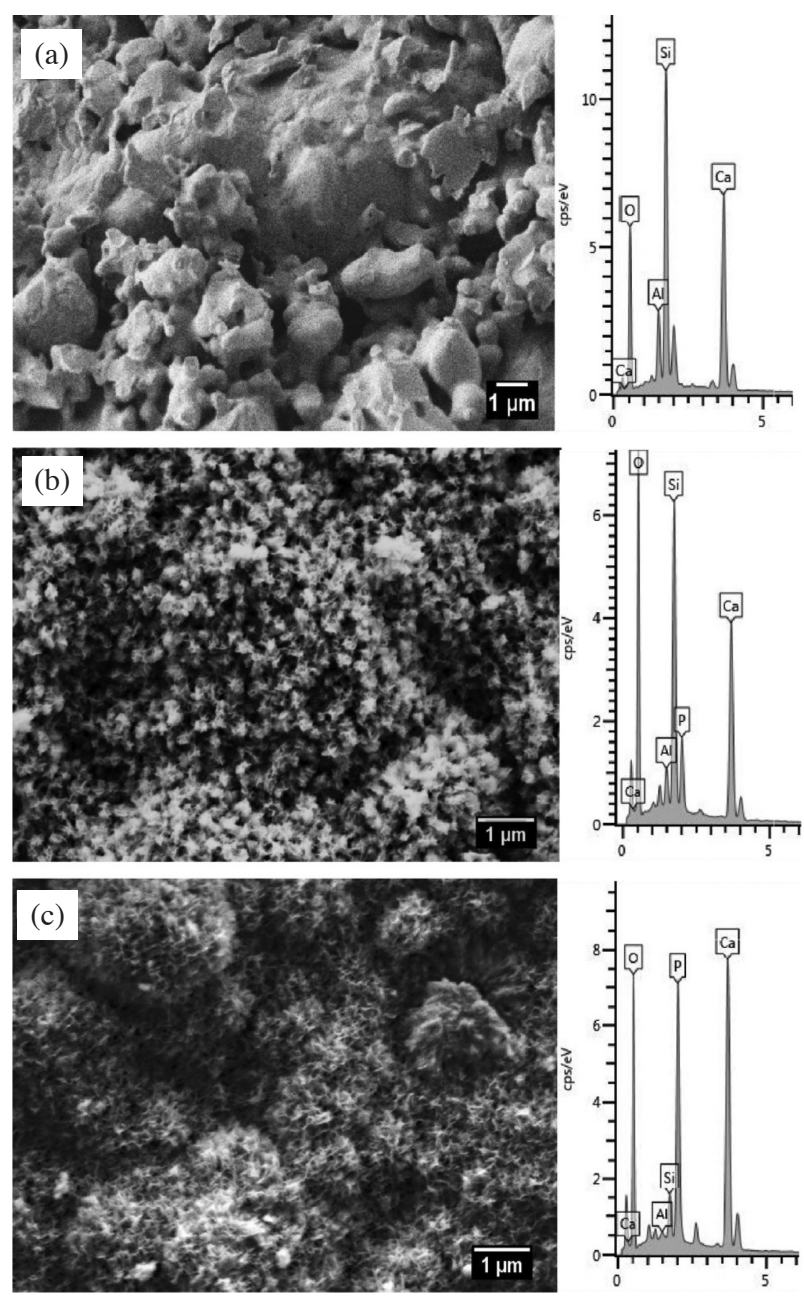

FIGURE 8. SEM morphology of the PSW20M composite sintered at $1150^{\circ} \mathrm{C}$ after soaking for (a) 0 and (b) 7 and (c) 14 days in the SBF solution 
from the natural resources of rice husk ash limestone and natural mullite have the promising mechanical properties as well as good bioactivity which have the potential for implant in biomedical application. In future, cytotoxicity and live-dead assays will be performed on human cells and behavior of this composite in vivo will be examined.

\section{ACKNOWLEDGEMENTS}

The authors gratefully acknowledge the Ministry of Science, Technology \& Innovative Malaysia (MOSTI) for supporting this research via the research grant, TRGS/2/2014/UKM/02/4/3. We also thank the Malaysian Ministry of Higher Education (MOHE), Malaysia for the financial support through MyBrain 15 scholarship, and the Centre of Research and Instrumentation for providing the research facilities.

\section{REFERENCES}

Anjaneyulu, U.\& Sasikumar, S. 2014. Bioactive nanocrystalline wollastonite synthesized by sol-gel combustion. Materials Science 37(2): 207-212.

ASTM C 496/C 496M - 04. 2011. Standard Test Method for Splitting Tensile Strength of Cylindrical Concrete Specimens. Annual Book of ASTM Standards Volume 04.02. pp. 1-5.

Bakr, I.M. 2012. Sintering of mullite with the aid of wollastonite. InterCeram: International Ceramic Review. pp. 58-62.

Best, S.M., Porter, A.E., Thian, E.S. \& Huang, J. 2008. Bioceramics: Past, present and for the future. Journal of the European Ceramic Society 28(7): 1319-1327.

Bieniawski, Z.T. \& Hawkes, I. 1978. Suggested methods for determining tensile strength of rock materials. International Society for Rock Mechanics Commission on Standardization of Laboratory and Field Tests 15: 99-103.

Cannillo, V., Colmenares-Angulo, J., Lusvarghi, L., Pierli, F. \& Sampath, S. 2009. In vitro characterisation of plasmasprayed apatite/wollastonite glass-ceramic biocoatings on titanium alloys. Journal of the European Ceramic Society 29(9): 1665-1677.

Chen, C.C., Ho, C.C., Lin, S.Y. \& Ding, S.J. 2015. Green synthesis of calcium silicate bioceramic powders. Ceramics International 41(4): 5445-5453.

De Aza, P.N., De Aza, A.H., Herrera, A., Lopez-Prats, F.A. \& Pena, P. 2006. Influence of sterilization techniques on the in vitro bioactivity of pseudowollastonite. Journal of the American Ceramic Society 89(8): 2619-2624.

De La Casa-Lillo, M.A., Velásquez, P. \& De Aza, P.N. 2011. Influence of thermal treatment on the in vitro bioactivity of wollastonite materials. Journal of Materials Science: Materials in Medicine 22(4): 907-915.

Ding, S.J., Shie, M.Y. \& Wang, C.Y. 2009. Novel fast-setting calcium silicate bone cements with high bioactivity and enhanced osteogenesis in vitro. Journal of Materials Chemistry 19(8): 1183-1190.

Dorozhkin, S.V. 2007. Biomaterials for medicine. Glass and Ceramics 64: 442-447.

Elghazel, A., Taktak, R. \& Bouaziz, J. 2015. Determination of elastic modulus, tensile strength and fracture toughness of bioceramics using the flattened Brazilian disc specimen: Analytical and numerical results. Ceramics International 41(9): 12340-12348.
Engqvist, H., Edlund, S., Gomez-Ortega, G., Loof, J. \& Hermansson, L. 2006. In vitro mechanical properties of a calcium silicate based bone void filler. Key Engineering Materials 309-311: 829-832.

Gautier, S., Champion, E. \& Bernache-Assollant, D. 1997. Processing, microstructure and toughness of $\mathrm{Al} 2 \mathrm{O} 3$ plateletreinforced hydroxyapatite. Journal of the European Ceramic Society 17(11): 1361-1369.

Hamisah, I., Shamsudin, R., Abdul Hamid, M.A. \& Rozidawati, A. 2016. Mechanism of apatite formation on $\beta$-wollastonite sample surface synthesized from rice husk ash. Sains Malaysiana 45(12): 1779-1785.

Hamisah,I., Shamsudin, R., Abdul Hamid, M.A. \& Jalar, A. 2013. Synthesis and characterization of nano-wollastonite from rice husk ash and limestone. Materials Science Forum 756: 43-47.

Harabi, A. \& Chehlatt, S. 2013. Preparation process of a highly resistant wollastonite bioceramics using local raw materials. Journal of Thermal Analysis and Calorimetry 111(1): 203211

Horng, Y.J. \& Min, H.H. 1994. Fabrication and mechanical properties of hydroxyapatite-alumina composites. Materials Science and Engineering: C 2(1-2): 77-81.

Hsu, Y.H., Turner, I.G. \& Miles, A.W. 2007. Mechanical characterization of dense calcium phosphate bioceramics with interconnected porosity. Journal of Materials Science: Materials in Medicine 18(12): 2319-2329.

Ji, H. \& Marquis, P.M. 1992. Preparation and characterization of $\mathrm{Al}_{2} \mathrm{O}_{3}$ reinforced hydroxyapatite. Biomaterials 13(11): 744-748.

Kim, H.W., Kong, Y.M., Koh, Y.H., Kim, H.E., Kim, H.M. \& Ko, J.S. 2003. Pressureless sintering and mechanical and biological properties of fluor-hydroxyapatite composites with zirconia. Journal of the American Ceramic Society 86(12): 2019-2026.

Kokubo, T. \& Takadama, H. 2006. How useful is SBF in predicting in vivo bone bioactivity? Biomaterials 27(15): 2907-2915.

Liu, X. \& Ding, C. 2002. Characterization of plasma sprayed wollastonite powder and coatings. Surface and Coatings Technology 153(2001): 173-177.

Maitra, S., Rahaman,A., Sarkar,A. \& Tarafdar,A. 2006.Zirconiamullite materials prepared from semi-colloidal route derived precursors. Ceramics International 32(2): 201-206.

Marghussian, V.K. \& Sheikh-Mehdi Mesgar, A. 2000. Effects of composition on crystallization behaviour and mechanical properties of bioactive glass-ceramics in the $\mathrm{MgO}-\mathrm{CaO}$ $\mathrm{SiO} 2-\mathrm{P} 2 \mathrm{O} 5$ system. Ceramics International 26(4): 415-420.

Nath, S., Dubey, A.K. \& Basu, B. 2012. Mechanical properties of novel calcium phosphate-mullite biocomposites. Journal of Biomaterials Applications 27(1): 67-78.

Nath, S., Kalmodia, S. \& Basu, B. 2011. In vitro biocompatibility of novel biphasic calcium phosphate-mullite composites. Journal of Biomaterials Applications 27(5): 497-509.

Nath, S., Kalmodia, S. \& Basu, B. 2010. Densification, phase stability and in vitro biocompatibility property of hydroxyapatite-10 wt. \% silver composites. Journal of Materials Science. Materials in Medicine 21(4): 1273-1287.

Nath, S., Biswas, K. \& Basu, B. 2008. Phase stability and microstructure development in hydroxyapatite-mullite system. Scripta Materialia 58(12): 1054-1057.

Osendi, M.I. \& Baudı 'n, C. 1983. Mechanical properties of mullite materials. Journal of the American Ceramic Society 66(10): 699-703 
Park, J.B. \& Bronzino, J.D. 2002. Biomaterials: Principles and Applications. Boca Raton: CRC Press.

Pilliar, R.M., Filiaggi, M.J., Wells, J.D., Grynpas, M.D. \& Kandel, R.A. 2001. Porous calcium polyphosphate scaffolds for bone substitute applications-in vitro characterization. Biomaterials 22: 963-972.

Schneider, H., Schreuer, J. \& Hildmann, B. 2008. Structure and properties of mullite- A review. Journal of the European Ceramic Society 28(2): 329-344.

Shirazi, F.S., Mehrali, M., Oshkour, A.A., Metselaar, H.S.C., Kadri, N.A. \& Abu Osman, N.A. 2014. Mechanical and physical properties of calcium silicate/alumina composite for biomedical engineering applications. Journal of the Mechanical Behavior of Biomedical Materials 30: 168-175.

Silva, V.V., Lameiras, F.S. \& Domingues, R.Z. 2001. Microstructural and mechanical study of zirconiahydroxyapatite $(\mathrm{ZH})$ composite ceramics for biomedical applications. Composites Science and Technology 61(2): 301-310.

Zhang, J., Iwasa, M., Kotobuki, N., Tanaka, T., Hirose, M., Ohgushi, H. \& Jiang, D. 2006. Fabrication of hydroxyapatitezirconia composites for orthopedic applications. Journal of the American Ceramic Society 89(11): 3348-3355.

Zhao, J.C., Smith, J.F., Schiffman, R.S. \& Merchant, S.M. 2007. Methods for Phase Diagram Determination. New York: Elsevier.
Farah 'Atiqah Abdul Azam, Roslinda Shamsudin*, Zalita Zainuddin \& Muhammad Azmi Abdul Hamid School of Applied Physics

Faculty of Science and Technology

Universiti Kebangsaan Malaysia

43600 UKM Bangi, Selangor Darul Ehsan

Malaysia

Min Hwei Ng

Tissue Engineering Centre

$12^{\text {th }}$ Floor, Clinical Block

UKM Medical Centre

56000 Cheras, Kuala Lumpur, Wilayah Persekutuan

Malaysia

Rashita Abdul Rashid

Mineral Research Centre, Minerals, and Geoscience Department 31400 Ipoh, Perak Darul Ridzuan Malaysia

*Corresponding author; email: linda@ukm.edu.my

Received: 14 March 2018

Accepted: 2 June 2018 